\title{
PHILOSOPHICAL THOUGHTS OF AUROBINDO: ITS IMPACT ON MODERN EDUCATIONAL SYSTEM
}

\author{
Dr. Hazarat Ali Seikh \\ Assistant Professor, \\ Lalgola College
}

\begin{abstract}
Aurobindo Ghosh was a multifaceted genius - a great philosopher, a freedom fighter, an eminent educationist and a true Yogi. He started his journey as a political thinker and became a spiritual integralist. He showed us the path to the highest spiritual growth. His educational philosophy was based on his philosophy of life i.e., on brahmacharya, practice of Yoga and spiritual penance. He believed in integral education, based on his philosophy of education, leading man to the fullest extent through harmonious development of his self physical, vital, mental, psychic and spiritual. He translated his ideals into a system of education through his Pondicherry Ashram School, now named as Auroville.
\end{abstract}

Key words: Integration of thought, superman.

\section{OBJECTIVES OF THE STUDY}

The present study has the following objectives

i) To understand the life philosophy and educational philosophy of Aurobindo.

ii) To understand some concepts of education given by him.

iii) To critically estimate the impact of his thoughts on present system of education.

\section{PHILOSOPHY OF LIFE}

Aurobindo's life philosophy is a synthesis of idealism, realism, naturalism and pragmatism. According to him, Jnana (knowledge), Bhakti (devotion) and Karma (work ethics) can lead man to the divine path. But synthesis of spirituality, creativeness and intellectuality is essential for a sound personality. Spirituality is the master key of the Indian mind. He had also faith in creativeness of India and its strong intellectuality.

\section{INTEGRATION OF THOUGHT}

A balance between the multicoloured shades of life makes life as a whole. He had a great faith in the Gita that there should be a proper balance among knowledge, devotion and work. God, the Purushothama can be achieved through Nishkam Karma, never-ending meditation, devotion and feeling of unity of all things in God. So Aurobindo was strong supporter of the basic unity of truth through synthesising the different views of Indian thoughts. Such integral approach can solve various problems of human life.

\section{SUPER MIND AND SUPERMAN:}

According to him, mind of man is imperfect and it can be transformed into super mind which can have an understanding of the integral truth. He said, "Man will become a super mind. Super mind will have a super mental consciousness. Consciousness of Sat-Chit-Anand" (Ravi, 2011). When one attains a super mind, he becomes a superman. Such transformations is possible through Purna Yoga, which can further help one to realise the supreme, the Purushothama.

\section{EVOLUTION OF MAN}

According to Aurobindo, individual soul is in the continuous process of evolution to attain the supreme soul. To him, "Life is not for life alone, but for God. There is an inner law and meaning for all things depending on the supreme." (Ravi, 2011)

If we neglect such inner laws \& spirituality, it will result in the decay of human societies. He remarked, "the radical defect of all civilization has been the neglect of the spiritual elements" (Ravi, 2011).

\section{PHILOSOPHY OF EDUCATION}

Aurobindo believed in the synthesis of the idealism, realism, naturalism and pragmatism. $\mathrm{He}$ tried to translate his philosophical ideals into a system of education that would help the young child to develop his interest, creativity, mental, moral and aesthetic senses. True education should focus on the four layers of mind-chitta, manas, buddhi and intuition. Chitta is the passive memory and needs no training. Manas is the sixth sense. Buddhior intellect works at the higher level of judgement, manipulation and generalisationor 


\section{International Journal of Engineering Applied Sciences and Technology, 2020 \\ Vol. 5, Issue 8, ISSN No. 2455-2143, Pages 232-234 \\ Published Online December 2020 in IJEAST (http://www.ijeast.com)}

conclusion. Intuition brings direct vision of knowledge.

Education, in its true sense should bring out the latent powers of child to make him complete in every respect. In his words, "Education is helping the growing soul to draw out that is in itself (Ravi, 2011). Education that ensures complete or integral development i.e., physical, vital, mental, psychic and spiritual aspects of the child, is called integral education. Such education can give the child a flexible shape so that he may be able to face challenges and meet the changing and growing needs of complex life.

\section{PRINCIPLES OF EDUCATION}

1) Education should be learner - centric.

2) Provision for full freedom for the child.

3) Should meet the psychological needs of the child.

4) Should bring out the latent powers of the child.

5) Should develop all the faculties of the child.

6) Should be related to the life of the child.

7) Medium of instruction should be mother tongue.

8) Emphasis on sense training.

9) Should develop consciousness of the child.

10)Religious education and spiritual development through brahmacharya should be a part of education.

\section{AIM OF EDUCATION}

According is Aurobindo education should have the following aims:

1) Development of latent potentialities of the child.

2) Development of physical purity, mental faculties, culture and aesthetic senses.

3) To train all the senses as senses are the gateways of knowledge.

4) Development of conscience -chitta, manas, knowledge and intuition.

5) Moral and emotional development.

6) Development of spirituality through Yoga \&brahmacharya.

7) Realisation of the self is must for education.

\section{Method of Teaching:}

In a child - centric set - up, child should be given full freedom with love and sympathy. Following methods should be followed.

1) Self - learning \& experiences should be encouraged.

2) Learning by doing should be followed.
3) Co - operative learning on the basis of cooperative activities.

4) According to 3 A's i.e. age, ability and aptitude of the child.

\section{Curriculum:} followed.

Following five principles should be

1) Curriculum should be made interesting for the child.

2) Variety of subjects and activities should be included.

3) Curriculum must have a scope to motivate the child to learn.

4) Curriculum must promote the creative potentialities.

5) Curriculum must ensure the attainment of up to date knowledge.

Different subjects \& activities for various development are given below.

1) For physical development: Physical training, games, gymnastics \& health education.

2) Vital development: Music, fine art, dance, drama, craft.

3) Mental development: Language, Mathematics, Social \& applied sciences.

4) Moral Development: Noble habits, right emotions, associations \& actions, training of Raja Yoga.

5) Psychic \& spiritual development: Practice of values - love \& truth and faith in God.

6) Vocational aspect: Arts, Painting, Drawing, Sculpture, Carpentry, Music, Nursing, Dance, Drama, Engineering.

7) International aspects: International understanding, fellow feeling, international love \& sympathy.

\section{ROLE OF TEACHER}

The teacher should play a vital role in the process of education through inculcation of selfcontrol, humanityand spiritual equality. According to Aurobindo, "one must be a saint and a hero to be a good teacher". "The teacher is not an instructor or task master, he should be a helper \& guide. His business is to suggest and not to impose. He does not impart knowledge to him. He shows him how to acquire knowledge for himself'(Ravi, 2011). So the teacher should not impose anything on the child. Rather as a helper \& guide he should stimulate the child to develop himself naturally with full freedom.

Critical Evaluation of philosophical thoughts of Aurbindo: 


\section{International Journal of Engineering Applied Sciences and Technology, 2020 Vol. 5, Issue 8, ISSN No. 2455-2143, Pages 232-234 \\ Published Online December 2020 in IJEAST (http://www.ijeast.com)}

Aurobindo was a distinguished philosopher and educationist who formulated rich philosophical ideas and educational thoughts to enrich our educational system comprehensively. Following thoughts are relevant today and should be adopted to solve the problems of our educational system.

1) Child - centric education with full freedom of the child to express his latent potentialities.

2) Introduction of moral and religious education as an integral part of general education and by practice of religious life.

3) Introduction of Yoga education and education of mind to strengthen the power of mind and intellect through increasing concentration \& attention.

4) Training of the senses as senses are the gateways of knowledge.

5) Mother tongue as a medium of instruction.

6) Emphasis on Psychological methods i.e. self - learning, practical experiences, learning by doing, teaching according to age, abilities \& aptitude of the child.

7) Varied \& comprehensive curriculum to prepare the child for life.

8) Crucial role of teacher as helper \& guide in integral education.

9) International education based on universal love, sympathy, fellow feeling, peace \&international understanding.

10) Reconstruction of National System of education to meet needs, aspirations \& soul of our nation.

\section{CONCLUSION}

So we may conclude that his educational thoughts are comprehensive, very much relevant, modern, and psychological in nature. His integral education can combine human body, mind, intellect $\&$ soul together to meet full purpose of life. He was a great supporter of national system of education which is associated with his integral education. Through such national system of education we can achieve national integrity, preserve and promote our culture and tradition. As a result national reconstruction will be achieved.

\section{REFERENCES}

Taneja, V.R. (2004) Educational thought and practice(P. 48-57), sterling publishers, new delhi,

2) Aggarwal, J.C. and S. Gupta (2006) Great philosophers and thinkers on Education(P. 30-50), Shipra Publication, New Delhi.

3) Ravi, S.S. (2011) A comprehensive study of Education(P. 260-282), PHI Learning Pvt. Ltd., New Delhi
4)Sri Aurobindo(1969) The foundations of Indian Culture(P. 236-308), Sri Aurobindo Society, Kolkata.

5) Aggarwal, J.C. (2002), Theory \& Principles of Education (P.150-155) Vikas Pub. House

6) Brubacher, J.S. (2007) Modern Philosophies of Education (P. 140-148), Surjeet Pub.

7) Chauhan, C.P.S. (2004) Modern Indian Education (P. 78-85) Kaniska Pub.

8) Dash, M. (2004) Education In India, (P. 112118) Atlantic pub.

9) Sharma, S.R. (2003) Principles of Education (P. 90-95) Mohit Pub.

10) Pruti, R.K. (2005) Education in Modern India (P. 110-115) Sonali Pub.

11) Mehta, D.D. (2003) Development of Education system in India (P. 82-87) Tendon Pub.

12) Johri, P.K. (2005) Foundation of Education (P. 152-158) Anmol Pub., New Delhi

Email :ㅁ.hazarataliseikh@gmail.com

18/11, K.K. BANERJEE ROAD, BERHAMPORE, MURSHIDABAD, 742101 